\title{
PERSEPSI KESIAPAN KERJA MAHASISWA SETELAH MELAKSANAKAN KERJA PRAKTIK INDUSTRI (KPI) PADA PRODI PENDIDIKAN INFORMATIKA
}

\author{
Etistika Yuni Wijaya ${ }^{1}$, Nuru Aini ${ }^{2}$ \\ ${ }^{1}$ Jurusan Prodi Pendidikan Informatika \\ Universitas Trunojoyo Madura \\ Madura, Indonesia \\ etistikaw@gmail.com
}

\begin{abstract}
Abstrak
Penelitian ini bertujuan untuk mengetahui kesiapan kerja mahasiswa prodi pendidikan informatika angkatan 2017 yang telah melaksanakan Kerja Praktik Industri (KPI). Penelitian ini merupakan penelitian deskriptif kuantitatif yang dilakukan di Prodi Pendidikan Informatika. Populasi yang digunakan adalah 49 mahasiswa Prodi Pendidikan Informatika angkatan 2017. Teknik pengumpulan data menggunakan angket tertutup (kuesioner). Teknik analisis data yang digunakan adalah deskriptif. Hasil penelitian diketahui bahwa persepsi kesiapan kerja mahasiswa setelah melaksanakan Kerja Praktik Industri (KPI) pada Prodi Pendidikan Informatika dijabarkan menjadi Sembilan indikator. Persepsi kesiapan kerja mahasiswa setelah melaksanakan Kerja Praktik Industri (KPI) pada Prodi Pendidikan Informatika dijabarkan menjadi Sembilan indikator, yaitu: (a) menguasai teori dan praktik; (b) memiliki Kematangan kompetensi, fisik, mental, pengalaman, informasi dan kemampuan untuk bekerja; (c) memiliki pertimbangan logis dan objektif; (d) mampu menyelesaikan tugas; (e) mengetahui wawasan tentang dunia kerja; (f) mampu mengoperasikan suatu alat sesuai dengan SOP; (g) mampu menyesuaikan diri dengan lingkungan sekitar dan mudah bergaul dengan rekan kerja; (h) mampu bersikap kritis; dan (i) mampu menerima tanggung jawab atas pekerjaannya. Hasil penelitian tertinggi terletak pada indikator 1 menguasai teori dan praktik menunjukkan skor perolehan rata-rata adalah $71,4 \%$ dimana memiliki kategori sebagian besar.
\end{abstract}

Kata kunci:Kerja Praktik Industri, Kesiapan Kerja, Pendidikan, Informatika 


\begin{abstract}
This study aims to determine the readiness of the 2017 informatics education study program students who have carried out Industrial Practical Work (KPI). This research is a quantitative descriptive study conducted in the Informatics Education Study Program. The population used was 49 students of the Informatics Education Study Program class 2017. Data collection techniques used a closed questionnaire (questionnaire). The data analysis technique used is descriptive. The results of the study show that perceptions of student work readiness after carrying out Industrial Practical Work (KPI) in the Informatics Education Study Program are translated into nine indicators, perceptions of student work readiness after carrying out Industrial Practical Work (KPI) in the Informatics Education Study Program are translated into nine indicators, namely: (a) mastering theory and practice; $(b)$ have the Maturity of competence, physical, mental, experience, information and ability to work; (c) have logical and objective considerations; $(d)$ able to complete the task; (e) knowing insight into the world of work; $(f)$ able to operate a tool in accordance with the SOP; $(g)$ able to adapt to the surrounding environment and easy to get along with colleagues; $(h)$ able to be critical; and $(i)$ able to accept responsibility for their work. The highest research result lies in indicator 1 of mastering theory and practice, showing the average score of $71.4 \%$, which is in the majority category.
\end{abstract}

\title{
Keywords: Industrial Practical Work, Work Readiness, Education, Informatics
}




\section{PENDAHULUAN}

Abad 21 memiliki peran perubahan dalam segala aspek kehidupan manusia. Perubahan transisi dari masyarakat industri ke masyarakat berbasis pengetahuan (knowledge age) memengaruhi beberapa aspek, baik budaya maupun pendidikan. Perubahan itu juga turut memengaruhi berbagai keterampilan yang perlu dikuasai mahasiswa agar bisa sukses di masa depan (Wijaya, 2016). Menurut (Trilling \& Fadel, 2009) menjelaskan keterampilan abad ke21 meliputi kecakapan hidup dan berkarir (life and career skills), keterampilan belajar dan berinovasi (learning and inovation skills) dan keterampilan teknologi dan media informasi (information media and technoloy skills).

Peningkatan kompetensi guru perlu diperbaiki melalui kompetensi pedagogik, profesional, kepribadian, dan kompetensi sosial. Kemampuan guru profesional dituntut tidak hanya untuk mengajar sebagaimana disyaratkan dalam standar kompetensi pedagogik, tetapi juga harus mampu dalam mengembangkan profesionalitas (Tridiana, 2020). Salah satu upaya peningkatan kompetensi profesional guru adalah adanya peran LPTK dalam menghasilkan lulusan guru yang berkualitas sesuai dengan tuntutan abad 21. Prodi Pendidikan Informatika Fakultas Ilmu Pendidikan Universitas Trunojoyo Madura sebagai Lembaga Pendidikan Tenaga Kependidikan (LPTK) dan lembaga penghasil tenaga Sarjana Pendidikan terus mengembangkan kegiatan-kegiatan yang selaras dengan tuntutan profesi berdasarkan perkembangan IPTEK.

Menurut Mukhadis (2014) lulusan yang unggul memiliki ciri-ciri: (1) Godly character (berakhlak pada multi latar: peka emosi dan intelektual, empati horizontal dan vertikal, serta teguh jati diri; (2) Excellent competence (akrab/fasih teknologi, dan berkearifan lokal); (3) kemandirian berfikir (answering question, questioning answering, dan questioning question); (4) sustainable self learning dan sustainable self development; dan (5) spritual discernment (tawadu dan keikhlasan yang tinggi). Oleh sebab itu setidaknya proses pendidikan calon guru dapat mengarahkan mahasiswa untuk menguasai poin-poin yang menjadi ciri lulusan unggul.

Guru Pendidikan Informatika
dituntut untuk selalu membarui pengetahuan terutama di bidang Teknologi Informasi. Arah trend teknologi yang selalu berubah menuntut calon guru lulusan pendidikan informatika untuk selalui membarui keilmuan sesuai dengan keadaan dunia kerja. Calon guru lulusan Prodi Pendidikan Informatika harus bersiap-siap sesuai dengan keadaan abad 21. Peran penyiapan dimaksud adalah adopsi pendekatan holistik dari aspek pengetahuan, keterampilan, dan sikap terhadap perkembangan kemampu-kerjaan (employability) dan berperan sebagai anggota masyarakat yang mandiri dan bertanggung jawab dengan program pendidikan yang menekankan pada pengembangan nilai, etika, dan perilaku (Sudjimat, 2011).

Peningkatan kompetensi calon guru Prodi Pendidikan Informatika tidak hanya mencakup aspek tentang skill di bidang informatika melainkan pengabungan dengan sikap, tanggung jawab kerja, adaptasi, penyelesaian masalah (problem solving) agar mereka mampu bekerja pada bidangnya dengan sukses. 
Calon guru lulusan Prodi Pendidikan Informatika harus dibekali dengan kompetensi profesional yang cukup kuat sebelum mahasiswa terjun seutuhnya di dunia kerja. Kompetensi profesional mahasiswa pendidikan informatika adalah :

(a) memiliki kemampuan penguasaan bidang keahlian teknologi informasi; (b) kemampuan berpikir dan berkomunikasi secara akademis dan etis; (c) memiliki kemampuan yang luas tentang isu-isu mutakhir dalam bidang yang diajarkan; dan (d) memiliki kemampuan untuk mengembangkan bidang teknologi informasi lewat penelitian dan karya rancangan.

Calon guru lulusan Prodi Pendidikan Informatika tidak hanya dibekali dengan hard skills berupa kecakapan kognitif dan teknikal kepada para mahasiswa tetapi juga harus mampu mengembangkan soft skills berupa attitudes dan work habits, atau berupa kecakapan kemampu-kerjaan (Sudjimat, 2011). Salah satu upaya membekali kompetensi mahasiswa agar memiliki kemampuan hard skills dan soft skills adalah melalui mata kuliah yang menjembatani antara dunia pendidikan dengan dunia nyata melalui mata kuliah Kerja Praktik Industri (KPI). Mata kuliah KPI disusun berdasarkan KKNI dan profil lulusan Prodi Pendidikan Informatika. Adapun profil lulusan Prodi Pendidikan Informatika adalah: (a) tenaga pendidik; (b) tenaga ahli; (c) tenaga kependidikan; dan (d) technopreneur.

Mahasiswa Prodi Pendidikan Informatika, Fakultas Ilmu Pendidikan, Universitas Trunojoyo Madura yang akan menyelesaikan studinya dalam program $\mathrm{S} 1$ Pendidikan Informatika harus telah menempuh semua mata kuliah wajib dengan beban sks seperti yang telah ditentukan dalam kurikulum. Diantara mata kuliah-mata kuliah tersebut terdapat mata kuliah KPI yang dilaksanakan di perusahaan-perusahaan atau instansi di luar UTM, yang wajib dilaksanakan mahasiswa dengan bobot 2 sks. Mata kuliah KPI adalah seluruh aktivitas yang berhubungan dengan KPI, mulai dari pengajuan proposal, proses surat-menyurat dengan perusahaan, pelaksanaan KPI sampai selesai membuat laporan hingga keluarnya nilai akhir. Dalam menjalankan aktivitas KPI ini mahasiswa akan dibimbing seorang Dosen Pembimbing yang ditunjuk oleh koordinator KPI.

Untuk menunjang kegiatan KPI pada matakuliah ini, dosen koordinator KPI membuat panduan dan diberikan kepada mahasiswa. Sebelum mahasiswa melaksanakan KPI di lapangan, koordinator KPI akan melaksanakan kegiatan sosialisasi guna memberikan pemahaman terkait bentuk mata kuliah yang harus ditempuh, sistematika pencarian tempat KPI, sistematika pembimbingan KPI dan Pelaporan KPI. Dari uraian diatas dapat disimpulkan bahwa lulusan yang handal dari lembaga pendidikan terutama Prodi Pendidikan Informatika yang sesuai dengan tuntutan dunia usaha/industri adalah lulusan yang memiliki penguasaan kemampukerjaan yang baik.

Penelitian ini bertujuan untuk mendapatkan informasi mengenai persepsi kesiapan kerja mahasiswa setelah melaksanakan Kerja Praktik Industri (KPI) pada Prodi Pendidikan Informatika. Temuan penelitian ini diharapkan bermanfaat untuk bahan masukan bagi koordinator program studi Prodi Pendidikan Informatika dan dosen-dosen dalam 
meningkatkan kualitas pelaksanaan Kerja Praktik Industri.

\section{METODE PENELITIAN}

Pendekatan penelitian ini menggunakan pendekatan kuantitatif dengan metode penelitian deksriptif. Sugiyono (2006:11), penelitian deskriptif adalah penelitian yang dilakukan untuk mengetahui nilai variabel mandiri, baik satu variabel atau lebih (independen) tanpa membuat perbandingan atau menghubungkan dengan variabel lain. Penelitian ini dilakukan untuk menggambarkan keadaan obyek dan faktafakta yang bersangkutan serta tidak bermaksud untuk menguji hipotesis tetapi hanya menggambarkan apa adanya tentang Persespi kesiapan kerja mahasiswa Prodi Pendidikan Informatika Angkatan 2017 setelah melaksanakan kegiatan Kerja Praktik Industri (KPI).

Tempat penelitian ini adalah di Prodi Pendidikan Informatika, Fakultas Ilmu Pendidikan, Universitas Trunojoyo Madura. Penelitian dilakukan selama bulan Maret 2021 dengan menyebarkan angket kepada seluruh mahasiswa Prodi Pendidikan Informatika angkatan 2017. Variabel dalam penelitian ini merupakan variabel tunggal yaitu persepsi kesiapan kerja mahasiswa setelah melaksanakan Kerja Praktik Industri (KPI). Untuk menghindari adanya kesalahan dalam penafsiran tentang variabel dalam penelitian ini, maka peneliti membatasi pengertian dari variabel tersebut. Adapun definisi operasional variabelnya adalah sebagai berikut (a) menguasai teori dan praktik; (b) memiliki kematangan kompetensi, fisik, mental, pengalaman, informasi dan kemampuan untuk bekerja; (c) memiliki pertimbangan logis dan objektif; (d) mampu menyelesaikan tugas; (e) mengetahui wawasan tentang dunia kerja; (f) mampu mengoperasikan suatu alat sesuai dengan SOP; (g) mampu menyesuaikan diri dengan lingkungan sekitar dan mudah bergaul dengan rekan kerja; (h) mampu bersikap kritis; dan (i) mampu menerima tanggung jawab atas pekerjaannya.

Populasi adalah wilayah generalisasi yang terdiri atas subjek atau objek, yang memiliki kualitas dan karakteristik tertentu yang ditetapkan oleh peneliti untuk dipelajari dan kemudian ditarik kesimpulan (Sugiyono, 2010: 117).

Populasi pada penelitian ini adalah mahasiswa Prodi Pendidikan Informatika Angkatan 2017 setelah melaksanakan kegiatan Kerja Praktik Industri (KPI). Keseluruhan populasi pada penelitian ini dijadikan sampel penelitian. Skala pengukuran yang digunakan pada penelitian ini adalah skala likert. Skala likert digunakan untuk mengukur sikap, pendapat, dan persepsi seseorang atau kelompok orang tentang fenomena sosial (Sugiyono, 2011:93).

Teknik analisis deskriptif yang digunakan adalah dengan pemakaian tabel frekuensi, persentase rerata masing-masing butir digunakan Persamaan (1). Pada Persamaan (1) $\mathrm{P}$ adalah persentase yangg dicari, $\mathrm{F}$ adalah skor tiap indikator, dan $\mathrm{N}$ adalah skor ideal (Sudjana, 2005).

$\mathrm{P}=\frac{\mathrm{F}}{\mathrm{N}} \times 100$

Hasil perhitungan persentase kemudian dikonsultasikan pada kategori penafsiran skor dalam analisis deskriptif data sebagaimana pada Tabel 1. Tabel 1 dihasilkan berdasarkan teori skor distribusi normal. 
Tabel 1. Pedoman Interpretasi Data

\begin{tabular}{|c|l|l|}
\hline No & \multicolumn{1}{|c|}{ Presentase (\%) } & \multicolumn{1}{|c|}{ Kategori } \\
\hline 1 & $80,1-100$ & Pada umumnya \\
\hline 2 & $69,1-80$ & Sebagian besar \\
\hline 3 & $40,1-60$ & Sebagian kecil \\
\hline 4 & $20,1-40$ & Sedikit sekali \\
\hline 5 & $0-20$ & Sangat sedikit sekali \\
\hline
\end{tabular}

Tabel 2. Penafsiran Skor Analisis Deskriptif

\begin{tabular}{|c|l|l|}
\hline No & \multicolumn{1}{|c|}{ Presentase $\mathbf{( \% )}$} & \multicolumn{1}{c|}{ Kategori } \\
\hline 1 & $3,25-<4,00$ & Sangat Baik \\
\hline 2 & $2,50-<3,25$ & Baik \\
\hline 3 & $1,75-<2,50$ & Kurang Baik \\
\hline 4 & $1,00-<1,75$ & Tidak Baik \\
\hline
\end{tabular}

\section{HASIL PENELITIAN DAN PEMBAHASAN}

Penelitian dilaksanakan di Prodi Pendidikan Informatika, Fakultas Ilmu Pendidikan, Universitas Trunojoyo Madura terhadap mahasiswa yang telah melaksanakan KPI pada angkatan 2017. Penelitian ini dilaksanakan pada bulan Maret 2021. Persepsi kesiapan kerja mahasiswa setelah melaksanakan Kerja Praktik Industri (KPI) pada Prodi Pendidikan Informatika dijabarkan menjadi Sembilan indikator, yaitu: (a) menguasai teori dan praktik; (b) memiliki Kematangan kompetensi, fisik, mental, pengalaman, informasi dan kemampuan untuk bekerja; (c) memiliki pertimbangan logis dan objektif; (d) mampu menyelesaikan tugas; (e) mengetahui wawasan tentang dunia kerja; (f) mampu mengoperasikan suatu alat sesuai dengan SOP; (g) mampu menyesuaikan diri dengan lingkungan sekitar dan mudah bergaul dengan rekan kerja; (h) mampu bersikap kritis; dan (i) mampu menerima tanggung jawab atas pekerjaanya.

\section{a) Data hasil mahasiswa menguasai teori dan praktik.}

Tabel 3. Hasil Analisis Indikator Menguasai Teori dan Praktik

\begin{tabular}{|c|c|c|c|}
\hline No & Pernyataan & $\%$ & Kriteria \\
\hline 1 & $\begin{array}{l}\text { Setelah melaksanakan } \\
\text { KPI saya dapat menguasai } \\
\text { salah satu ilmu di bidang } \\
\text { informatika }\end{array}$ & 83,7 & $\begin{array}{c}\text { Pada } \\
\text { Umumnya }\end{array}$ \\
\hline 2 & $\begin{array}{l}\text { Setelah melaksanakan } \\
\text { KPI saya memperoleh } \\
\text { keterampilan bidang } \\
\text { informatika sesuai dengan } \\
\text { yang saya harapkan }\end{array}$ & 69,4 & $\begin{array}{c}\text { Sebagian } \\
\text { Besar }\end{array}$ \\
\hline 3 & $\begin{array}{lr}\text { Pengetahuan } & \text { saya dalam } \\
\text { bidang } & \text { informatika } \\
\text { memudahkan } & \text { saya } \\
\text { menguasai pekerjaan pada } \\
\text { saat KPI }\end{array}$ & 73,5 & $\begin{array}{c}\text { Sebagian } \\
\text { Besar }\end{array}$ \\
\hline 4 & $\begin{array}{l}\text { Saya mampu } \\
\text { mempraktikan teori yang } \\
\text { di dapat di kampus untuk } \\
\text { digunakan bekerja pada } \\
\text { saat KPI }\end{array}$ & 75,5 & $\begin{array}{c}\text { Sebagian } \\
\text { Besar }\end{array}$ \\
\hline 5 & $\begin{array}{l}\text { Saya bekerja pada bidang } \\
\text { KPI sesuai dengan } \\
\text { kompetensi yang ingin } \\
\text { saya pelajari di dunia kerja }\end{array}$ & 53,1 & $\begin{array}{c}\text { Sebagian } \\
\text { Kecil }\end{array}$ \\
\hline
\end{tabular}

Hasil penelitian pada indikator 1 jika dilihat pada Tabel 3 menunjukkan skor perolehan rata-rata adalah $71,4 \%$ dimana memiliki kategori sebagian besar artinya mahasiswa mampu menguasai teori dan praktek setelah melaksanakan KPI. Indikator terendah terdapat pada penguasaan kompetensi yang ingin dikuasai oleh mahasiswa belum sesuai dengan keinginan mahasiswa sebesar 53,1\%. Indikator 1 menunjukkan bahwa dengan adanya penguasaan terhadap teori dan praktik setelah melaksanakan KPI maka mahasiswa akan memiliki kesiapan kerja yang baik sebagai bekal untuk terjun ke dunia kerja sesungguhnya. Hal tersebut sesuai dengan pendapat (Arifin, 2014:51) bahwa kerja praktik dapat dijadikan sebagai cara atau sarana memperoleh tambahan pengetahuan, sikap serta kemampuan yang lebih kompleks hingga mampu mencetak SDM yang berkualitas. 
b) Data hasil mahasiswa memiliki kematangan kompetensi, fisik, mental, pengalaman, informasi dan kemampuan untuk bekerja.

Tabel 4. Hasil Analisis Indikator Memiliki Kematangan Kompetensi, Fisik, Mental, Pengalaman, Informasi dan Kemampuan untuk Bekerja.

\begin{tabular}{|c|c|c|c|}
\hline No & Pernyataan & $(\%)$ & Kriteria \\
\hline 1 & $\begin{array}{l}\text { Saya memiliki } \\
\text { kemampuan beradaptasi } \\
\text { yang baik selama } \\
\text { melaksanakan KPI }\end{array}$ & 59,2 & $\begin{array}{c}\text { Sebagian } \\
\text { Kecil }\end{array}$ \\
\hline 2 & $\begin{array}{lr}\text { Saya mudah bergaul } \\
\text { dengan teman di tempat } \\
\text { kerja } & \text { selama } \\
\text { melaksanakan KPI }\end{array}$ & 46,9 & $\begin{array}{c}\text { Sebagian } \\
\text { Kecil }\end{array}$ \\
\hline 3 & $\begin{array}{l}\text { Saya menghargai } \\
\text { pendapat orang lain untuk } \\
\text { dapat beradaptasi dengan } \\
\text { lingkungan baru di } \\
\text { tempat KPI }\end{array}$ & 59,2 & $\begin{array}{c}\text { Sebagian } \\
\text { Kecil }\end{array}$ \\
\hline
\end{tabular}

Hasil penelitian pada indikator 2 sesuai dengan Tabel 4 menunjukkan skor perolehan rata-rata adalah 55,1\% dimana memiliki kategori sebagian kecil artinya mahasiswa belum mampu menguasai kematangan kompetensi, fisik, mental, pengalaman, informasi dan kemampuan untuk bekerja setelah melaksanakan KPI. Hal ini dikarenakan beberapa kendala, berdasarkan wawancara dengan mahasiswa berfikir waktu selama KPI kurang lama dan terpotong libur sehingga belum merasakan dunia kerja yang sesungguhnya. Lama pelaksanaan KPI adalah idealnya 1 bulan, tetapi karena terpotong libur mahasiswa hanya melaksanakan KPI sebanyak 18 hari kerja aktif. Berdasarkan indikator 2 terdapat pernyataan bahwa sebagian besar mahasiswa mampu bergaul dengan teman di tempat kerja selama melaksanakan KPI dengan melihat skor pernyataan sebesar $46,9 \%$.
Hasil tersebut sesuai seperti yang dikemukakan oleh Syahroni ( 2014: 281) bahwa banyak fenomena pelaksanaan praktek kerja industri belum sesuai yang diharapkan seperti: 1) Penempatan siswa yang kurang sesuai dengan minat, bakat dan ilmu yang dimilikinya, (2) Masih adanya siswa yang belum mampu menyelesaikan tugas yang berkaitan dengan bidang keahliannya, (3) Masih banyaknya siswa yang menganggur dan tidak memiliki pekerjaan setelah menyelesaikan praktek kerja industri, (4) Semakin tingginya angka pelanggaran peraturan sekolah setelah siswa pulang dari praktek kerja industri.

\section{c) Data hasil mahasiswa memiliki pertimbangan logis dan objektif.}

Tabel 5 Hasil Analisis Indikator Memiliki Pertimbangan Logis dan Objektif

\begin{tabular}{|c|c|c|c|}
\hline No & Pernyataan & $(\%)$ & Kriteria \\
\hline 1 & $\begin{array}{l}\text { Saya berusaha sabar } \\
\text { dalam mengahdapi rakan } \\
\text { kerja KPI ketika marah }\end{array}$ & 73,5 & $\begin{array}{c}\text { Sebagian } \\
\text { Besar }\end{array}$ \\
\hline 2 & $\begin{array}{l}\text { Saya } \\
\text { kemampuan yang logis } \\
\text { untuk mengambil } \\
\text { keputusan terkait bidang } \\
\text { informatika pada saat } \\
\text { melaksanakan KPI }\end{array}$ & 73,5 & $\begin{array}{c}\text { Sebagian } \\
\text { Besar }\end{array}$ \\
\hline 3 & $\begin{array}{lr}\text { Saya } & \text { memiliki } \\
\text { ketertarikan } & \text { untuk } \\
\text { memperlajari } & \text { bidang } \\
\text { informatika } & \text { setelah } \\
\text { melaksanakan KPI }\end{array}$ & 59,2 & $\begin{array}{c}\text { Sebagian } \\
\text { Kecil }\end{array}$ \\
\hline 4 & $\begin{array}{l}\text { Saya } \\
\text { mengoptimalkan } \\
\text { ketertarikan saya di } \\
\text { bidang } \\
\text { setelah informatika } \\
\text { KPI }\end{array}$ & 67,3 & $\begin{array}{c}\text { Sebagian } \\
\text { Besar }\end{array}$ \\
\hline 5 & $\begin{array}{l}\text { Saya tertarik pekerjaan di } \\
\text { bidang informatika yang } \\
\text { memiliki ketelitian dan } \\
\text { konsentrasi tinggi }\end{array}$ & 73,5 & $\begin{array}{c}\text { Sebagian } \\
\text { Besar }\end{array}$ \\
\hline 6 & $\begin{array}{lr}\text { Saya } & \text { membaca } \\
\text { website,buku, atau jurnal } \\
\text { untuk } & \text { menambah } \\
\text { pengetahuan } & \text { di bidang } \\
\end{array}$ & 73,5 & $\begin{array}{c}\text { Sebagian } \\
\text { Besar }\end{array}$ \\
\hline
\end{tabular}




\begin{tabular}{|c|l|c|c|}
\hline No & \multicolumn{1}{|c|}{ Pernyataan } & $(\boldsymbol{\%})$ & Kriteria \\
$\begin{array}{l}\text { informatika selama } \\
\text { melaksanakan KPI }\end{array}$ & $\begin{array}{l}\text { Saya dapat } \\
\text { mengoptimalkan bakat } \\
\text { saya di bidang } \\
\text { informatika setelah } \\
\text { melaksanakan KPI }\end{array}$ & 73,5 & $\begin{array}{c}\text { Sebagian } \\
\text { Besar }\end{array}$ \\
\hline
\end{tabular}

Hasil penelitian pada indikator 3 sesuai Tabel 5 menunjukkan skor perolehan rata-rata adalah $70,57 \%$ dimana memiliki kategori sebagian besar artinya sudah memiliki kemampun dalam pertimbangan logis dan obyektif setelah melaksanakan KPI. Hasil dari KPI adalah menjadikan mahasiswa mampu untuk menambah kemampuan berfikir logis dan menjadi lebih objektif dalam bekerja sesuai dengan bidang keahlian di bidang Informatika.

Hal ini sesuai dengan pendapat (Purwaningsih, 2017) bahwa melalui kegiatan magang dapat meningkatkan kemampuan soft skills mahasiswa. Soft skills merupakan bentuk dari kecerdasan multiple intelligence. Hal tersebut sesuai dengan teori multiple intelligence (Gardener, 2013). Adapun multiple intelligence menurut Gardner (2013: 2139), yaitu kecerdasan linguistik, kecerdasan musikal, kecerdasan logis matematis, kecerdasan spasial, kecerdasan interpersonal, kecerdasan intrapersonal, kecerdasan naturalis, dan kecerdaan spiritual.

\section{d) Data hasil mahasiswa mampu menyelesaikan tugas.}

Hasil penelitian pada indikator 4 sesuai Tabel 6 menunjukkan skor perolehan ratarata adalah 69,84 \% dimana memiliki kategori sebagian besar artinya mahasiswa mampu menyelesaikan tugas yang diberikan selama melaksanakan KPI. Hal ini sesuai dengan penelitian Khalil (2015: 202-217) yang menyatakan bahwa magang dapat meningkatkan kemampuan profesional mahasiswa.

Tabel 6. Hasil Analisis Indikator Mampu Menyelesaikan Tugas

\begin{tabular}{|c|c|c|c|}
\hline No & Pernyataan & $(\%)$ & Kriteria \\
\hline 1 & $\begin{array}{l}\text { Saya mengerjakan tugas } \\
\text { semaksimal mungkin selama } \\
\text { KPI agar mendapat } \\
\text { pengalaman kerja sesuai } \\
\text { bidang yang saya minati }\end{array}$ & 63,5 & $\begin{array}{c}\text { Sebagian } \\
\text { Kecil }\end{array}$ \\
\hline 2 & $\begin{array}{l}\text { Saya mampu menghasilkan } \\
\text { salah satu produk di bidang } \\
\text { informatika } \\
\text { TKJ/RPL/MM) }\end{array}$ & 75,5 & $\begin{array}{c}\text { Sebagian } \\
\text { Besar }\end{array}$ \\
\hline 3 & $\begin{array}{l}\text { Saya memiliki pengalaman } \\
\text { baru di bidang informatika } \\
\text { setelah melaksanakan KPI }\end{array}$ & 61,2 & $\begin{array}{c}\text { Sebagian } \\
\text { Kecil }\end{array}$ \\
\hline 4 & $\begin{array}{l}\text { Saya akan memberikan } \\
\text { pendapat saya agar } \\
\text { memberikan kemajuan } \\
\text { kepada perusahaan }\end{array}$ & 75,5 & $\begin{array}{c}\text { Sebagian } \\
\text { Besar }\end{array}$ \\
\hline 5 & $\begin{array}{l}\text { Saya memiliki kemampuan } \\
\text { menggunakan software di } \\
\text { bidang informatika setelah } \\
\text { melaksanakan KPI }\end{array}$ & 73,5 & $\begin{array}{c}\text { Sebagian } \\
\text { Besar }\end{array}$ \\
\hline
\end{tabular}

Jika ditinjau dari sisi industri kemampuan mahasiswa dalam menyelesaikan tugas selama KPI adalah dapat membantu meringankan tugas perusahaan yang dijadikan tempat mahasiswa prodi pendidikan informatika untuk KPI. Hal tersebut juga sesuai dengan pendapat Lee dan Chao (Kipreos, 2016: 23) adalah peserta magang dapat memberikan ide-ide baru bagi perusahaan dan dapat membantu menyelesaikan proyek kecil sehingga dapat menghemat waktu dan usaha karyawan. 


\section{e) Data hasil mahasiswa mengetahui wawasan tentang dunia kerja.}

Tabel 7. Hasil Analisis Indikator Mengetahui Wawasan tentang Dunia

\begin{tabular}{|c|c|c|c|}
\hline No & Pernyataan & $(\%)$ & Kriteria \\
\hline 1 & $\begin{array}{lr}\text { Saya lebih } & \text { banyak } \\
\text { mendapatkan informasi } \\
\text { tentang dunia kerja } \\
\text { setelah KPI }\end{array}$ & 75,5 & $\begin{array}{c}\text { Sebagian } \\
\text { Kecil }\end{array}$ \\
\hline 2 & $\begin{array}{lr}\text { Saya } & \text { mendapatkan } \\
\text { tambahan } & \text { wawasan } \\
\text { tentang dunia kerja } \\
\text { setelah KPI }\end{array}$ & 75,5 & $\begin{array}{c}\text { Sebagian } \\
\text { Kecil }\end{array}$ \\
\hline 3 & $\begin{array}{l}\text { Saya dapat bekerja } \\
\text { dengan optimal dengan } \\
\text { cara meningkatkan } \\
\text { pengetahuan tentang } \\
\text { dunia industri dan } \\
\text { keterampilan saya di } \\
\text { bidang informatika }\end{array}$ & 73,5 & $\begin{array}{c}\text { Sebagian } \\
\text { Besar }\end{array}$ \\
\hline 4 & $\begin{array}{l}\text { Saya menambah } \\
\text { pengetahuan saya di } \\
\text { bidang informatika di luar } \\
\text { jam kuliah }\end{array}$ & 75,5 & $\begin{array}{c}\text { Sebagian } \\
\text { Kecil }\end{array}$ \\
\hline 5 & $\begin{array}{l}\text { Dengan bekal di bidang } \\
\text { informatika yang saya } \\
\text { dapatkan di kampus dan } \\
\text { Dunia Industri, saya akan } \\
\text { siap bekerja di dunia } \\
\text { industri yang sebenarnya. }\end{array}$ & 71,4 & $\begin{array}{c}\text { Sebagian } \\
\text { Besar }\end{array}$ \\
\hline
\end{tabular}

Hasil penelitian pada indikator 5 sesuai Tabel 7 menunjukkan skor perolehan rata-rata adalah $74,28 \%$ dimana memiliki kategori sebagian besar artinya mahasiswa memiliki wawasan tentang dunia kerja setelah melaksanakan KPI. Mahasiswa memiliki gambaran langsung bagaimana tempat kerja sesungguhnya, menggunakan alat kerja sesungguhnya dan menggunakan software sesuai dengan kebutuhan dunia kerja.

Selain kemampuan teknis dalam wawasan dunia kerja juga memiliki wawasan secara non teknis. Wawasan non teknis dalam dunia kerja juga disebut sebagai wawasan soft skills. Hal tersebut sesuai dengan penelitian Rugaiyah (2011: 209-219) juga menyimpulkan bahwa program magang dapat meningkatkan soft skills mahasiswa. Soft skills tersebut antara lain keterampilan berkomunikasi, keterampilan beradaptasi dalam pekerjaan, keterampilan mengelola kerja tim, keterampilan bersosialisasi, dan ketelitian dalam bekerja.

\section{f) Data hasil mahasiswa mampu mengoperasikan suatu alat sesuai dengan SOP.}

Tabel 8. Hasil Analisis Indikator

Mengoperasikan alat sesuai dengan SOP

\begin{tabular}{|c|l|c|c|}
\hline No & \multicolumn{1}{|c|}{ Pernyataan } & $(\%)$ & Kriteria \\
\hline 1 & $\begin{array}{l}\text { Saya mampu } \\
\text { mengoperasikan software } \\
\text { yang digunakan di tempat } \\
\text { KPI }\end{array}$ & 59,2 & $\begin{array}{l}\text { Sebagian } \\
\text { Kecil }\end{array}$ \\
\hline 2 & $\begin{array}{l}\text { Saya mengetahui alat-alat / } \\
\text { software bidang informatika } \\
\text { di tempat KPI }\end{array}$ & 59,2 & $\begin{array}{c}\text { Sebagian } \\
\text { Kecil }\end{array}$ \\
\hline 3 & $\begin{array}{l}\text { Saya mengetahui fungsi- } \\
\text { fungsi alat / software bidang } \\
\text { informatika di tempat KPI }\end{array}$ & 59,2 & $\begin{array}{c}\text { Sebagian } \\
\text { Kecil }\end{array}$ \\
\hline 4 & $\begin{array}{l}\text { Saya mampu untuk } \\
\text { menggunakan software baru } \\
\text { yang ada pada tempat KPI }\end{array}$ & 63,3 & $\begin{array}{c}\text { Sebagian } \\
\text { Kecil }\end{array}$ \\
\hline 5 & $\begin{array}{l}\text { Saya mampu melakukan } \\
\text { troubleshooting pada bidang } \\
\text { informatika pada saat } \\
\text { melaksanakan KPI }\end{array}$ & 49 & $\begin{array}{c}\text { Sebagian } \\
\text { Kecil }\end{array}$ \\
\hline
\end{tabular}

Hasil penelitian pada indikator 6 sesuai Tabel 8 menunjukkan skor perolehan rata-rata adalah 57,9\% dimana memiliki kategori sebagian kecil artinya mahasiswa belum mampu menguasai alat/software sesuai dengan SOP. Mahasiswa banyak yang mengeluh dengan penggunaan 
software baru di tempat KPI karena beberapa software memang tidak diajarkan di kampus.

Penggunaan software terutama yang KPI pada tempat software house akan menyesuaikan lagi dengan software yang digunakan, sehingga mahasiswa membutuhkan waktu untuk beradaptasi dengan software baru yang digunakan. Dengan durasi KPI yang cukup singkat belum memungkinkan mahasiwa menguasai software secara keseluruhan.

Hal tersebut sejalan dengan kendala selama KPI dalam penelitian Syahroni ( 2014: 281) banyak fenomena pelaksanaan praktek kerja industri belum sesuai yang diharapkan seperti: 1) Penempatan siswa yang kurang sesuai dengan minat, bakat dan ilmu yang dimilikinya, (2) Masih adanya siswa yang belum mampu menyelesaikan tugas yang berkaitan dengan bidang keahliannya, (3) Masih banyaknya siswa yang menganggur dan tidak memiliki pekerjaan setelah menyelesaikan praktek kerja industri, (4) Semakin tingginya angka pelanggaran peraturan sekolah setelah siswa pulang dari praktek kerja industri.

\section{g) Data hasil mahasiswa mampu menyesuaikan diri dengan lingkungan sekitar dan mudah bergaul dengan rekan kerja.}

Hasil penelitian pada indikator 7 sesuai Tabel 9 menunjukkan skor perolehan ratarata adalah 76,2 \% dimana memiliki kategori sebagian besar artinya mahasiswa mampu menyesuaikan diri dengan lingkungan selama melaksanakan KPI.

Adaptasi merupakan penyesuaian diri kepada sebuah ketidakpastian, baik dalam dunia kerja secara hard skills maupun soft skills. Kemampuan adaptasi digunakan mahasiswa untuk menyesuaikan keadaan yang berubah sewaktu-waktu, keterampilan ini diperlukan karena keadaan yang dinamis. Keterampilan adaptasi merupakan keterampilan dasar yang harus dimiliki mahasiswa jika ingin berhasil di dunia kerja nantinya.

Tabel 9. Hasil Analisis Indikator Menyesuaikan diri dengan lingkungan sekitar dan mudah bergaul dengan rekan kerja

\begin{tabular}{|c|c|c|c|}
\hline No & Pernyataan & $(\%)$ & Kriteria \\
\hline 1 & $\begin{array}{lr}\text { Dalam tugas } & \text { kelompok, } \\
\text { saya selalu } & \text { melakukan } \\
\text { pekerjaan } & \text { dengan } \\
\text { maksimal } & \end{array}$ & 75,5 & $\begin{array}{c}\text { Sebagian } \\
\text { Besar }\end{array}$ \\
\hline 2 & $\begin{array}{l}\text { Saya dapat menerima } \\
\text { kritik atau masukan dari } \\
\text { rekan kerja atau atasan } \\
\text { setelah KPI }\end{array}$ & 69,4 & $\begin{array}{c}\text { Sebagian } \\
\text { Besar }\end{array}$ \\
\hline 3 & $\begin{array}{l}\text { Saya akan melakukan } \\
\text { pekerjaan atau tugas } \\
\text { walaupun tugas tersebut } \\
\text { bukan tugas saya karena } \\
\text { adanya hal yang urgent } \\
\text { atau genting demi } \\
\text { kemajuan perusahaan }\end{array}$ & 83,7 & $\begin{array}{c}\text { Sebagian } \\
\text { Besar }\end{array}$ \\
\hline
\end{tabular}

Peran KPI dapat meningkatkan kemampuan mahasiswa menyesuaikan diri dengan lingkungan dan menjadikan mahasiswa memiliki kesiapan kerja yang baik sebelum lulus dari Prodi Pendidikan Informatika. Hal ini selaras dengan Sari (2012:70) bahwa terdapat peran yang efekif antara pengalaman praktik kerja industri terhadap kesiapan kerja, yang menunjukkan bahwa pembelajaran praktik industri yang dilaksanakan secara langsung di dunia usaha dan dunia industri berperan terhadap 
kesiapan peserta didik untuk memasuki dunia kerja.

\section{h) Data hasil mahasiswa mampu bersikap kritis.}

Tabel 10. Hasil Analisis Indikator bersikap kritis

\begin{tabular}{|c|c|c|c|}
\hline No & Pernyataan & $(\%)$ & Kriteria \\
\hline 1 & $\begin{array}{l}\text { Saya selalu } \\
\text { mengkomunikasikan } \\
\text { hal-hal yang menjadi } \\
\text { pekerjaan saya }\end{array}$ & 73,5 & $\begin{array}{c}\text { Sebagian } \\
\text { Besar }\end{array}$ \\
\hline 2 & $\begin{array}{l}\text { Saya dapat menerima } \\
\text { informasi dengan lebih } \\
\text { mengenai situasi di } \\
\text { dunia kerja setelah } \\
\text { mengikuti KPI } \\
\end{array}$ & 81,16 & $\begin{array}{c}\text { Pada } \\
\text { Umumnya }\end{array}$ \\
\hline 3 & $\begin{array}{l}\text { Saya selalu } \\
\text { berkomunikasi dengan } \\
\text { rekan kerja atau atasan } \\
\text { pada saat melaksanakan } \\
\text { pekerjaan. }\end{array}$ & 71,4 & $\begin{array}{c}\text { Sebagian } \\
\text { Besar }\end{array}$ \\
\hline 4 & $\begin{array}{l}\text { Menurut saya } \\
\text { komunikasi sangatlah } \\
\text { penting dalam hal } \\
\text { menunjang kelancaran } \\
\text { pekerjaan }\end{array}$ & 59,2 & $\begin{array}{c}\text { Sebagian } \\
\text { Kecil }\end{array}$ \\
\hline
\end{tabular}

Hasil penelitian pada indikator 8 sesuai Tabel 10 menunjukkan skor perolehan rata-rata adalah $71,35 \%$ dimana memiliki kategori sebagian besar artinya mahasiswa mampu berpikir kritis setelah melaksanakan KPI.

Salah satu proses keterampilan yang wajib dikuasi oleh mahasiswa adalah berpikir kritis. Berpikir kritis pada bidang informatika dapat digunakan untuk proses analisis data dan informasi. Proses pengelolalan data dan informasi juga digunakan agar mahasiswa tidak mudah terpancing dengan berita-berita hoax.

Hal tersebut juga sejalan dengan pentingnya mahasiswa Prodi Pendidikan Informatika untuk memiliki kemampuan berpikir kritis. Hal ini sejalan dengan
Keterampilan berpikir kritis dan kreatif diperlukan dalam pembelajaran sains termasuk komputer yang bertujuan untuk menanggapi masalah dalam masyarakat yang disebabkan oleh pengaruh perkembangan ilmu pengetahuan dan teknologi (Fatmawati, 2016; Rashid dan Muhammad, 2016).

\section{i) Data hasil mahasiswa mampu menerima tanggung jawab atas pekerjaanya.}

Tabel 11. Hasil Analisis Indikator Menerima Tanggung jawab

\begin{tabular}{|c|l|c|c|}
\hline No & \multicolumn{1}{|c|}{ Pernyataan } & $(\%)$ & Kriteria \\
\hline 1 & $\begin{array}{l}\text { Saya akan menjalankan } \\
\text { tugas yang diberikan kepada } \\
\text { saya dengan semaksimal } \\
\text { mungkin }\end{array}$ & 75,5 & $\begin{array}{l}\text { Sebagian } \\
\text { Besar }\end{array}$ \\
\hline 2 & $\begin{array}{l}\text { Saya tidak akan } \\
\text { menyalahkan orang lain atas } \\
\text { kesalahan yang saya lakukan }\end{array}$ & 80 & $\begin{array}{c}\text { Sebagian } \\
\text { Besar }\end{array}$ \\
\hline 3 & $\begin{array}{l}\text { Saya akan mengikuti } \\
\text { peraturan yang berlaku di } \\
\text { perusahaan tempat saya } \\
\text { bekerja }\end{array}$ & 75,5 & Sebagian \\
Besar
\end{tabular}

Hasil penelitian pada indikator 9 sesuai denan tabel 11 menunjukkan skor perolehan rata-rata adalah $77 \%$ dimana memiliki kategori sebagian besar artinya mahasiswa mampu menerima tanggung jawab selama melaksanakan KPI.

Mahasiswa mampu menerima tanggung jawab pekerjaan sesuai dengan bidang keahlian Informatika. Hal tersebut akan menguntungkan mahasiswa ketika lulus dari Universitas. Mahasiswa sudah siap dalam bekerja dan mengikuti era industri 4.0 dan memiliki keterampilan abad 
21 yang mengharuskan mahasiswa melek teknologi dan informasi. Keterampilan di bidang IT adalah salah satu incaran dunia kerja. Seluruh aspek dunia kerja memerlukan Teknologi Informasi. Hal ini sesuai yang disampaikan Gehrke et al (2015:13) yaitu pada sisi teknik, khususnya kemampuan dan kualifikasi berhubungan dengan IT, pemrosesan dan analisis data dan informasi, pemahaman pengorganiasian dan proses, dan kemampuan untuk bekerja dan berinteraksi modern secara prospektif bernilai tinggi untuk tenaga kerja yang terampil.

\section{KESIMPULAN DAN SARAN Kesimpulan}

Persepsi kesiapan kerja mahasiswa setelah melaksanakan Kerja Praktik Industri (KPI) pada Prodi Pendidikan Informatika dijabarkan menjadi Sembilan indikator, yaitu: (a) menguasai teori dan praktik indikator 1 menunjukkan skor perolehan rata-rata adalah $71,4 \%$ dimana memiliki kategori sebagian besar; (b) memiliki Kematangan kompetensi, fisik, mental, pengalaman, informasi dan kemampuan untuk bekerja indikator 2 menunjukkan skor perolehan rata-rata adalah 55,1 \% dimana memiliki kategori sebagian kecil; (c) memiliki pertimbangan logis dan objektif indikator 3 menunjukkan skor perolehan rata-rata adalah 70,57 \% dimana memiliki kategori sebagian besar; (d) mampu menyelesaikan tugas indikator 4 menunjukkan skor perolehan rata-rata adalah 69,84 \% dimana memiliki kategori sebagian besar; (e) mengetahui wawasan tentang dunia kerja indikator 5 menunjukkan skor perolehan rata-rata adalah 74,28 \% dimana memiliki kategori sebagian besar; (f) mampu mengoperasikan suatu alat sesuai dengan SOP indikator 6 menunjukkan skor perolehan rata-rata adalah 57,9 \% dimana memiliki kategori sebagian kecil; (g) mampu menyesuaikan diri dengan lingkungan sekitar dan mudah bergaul dengan rekan kerja indikator 7 menunjukkan skor perolehan rata-rata adalah 76,2 \% dimana memiliki kategori sebagian besar; (h) mampu bersikap kritis indikator 8 menunjukkan skor perolehan rata-rata adalah $71,35 \%$ dimana memiliki kategori sebagian besar; dan (i) mampu menerima tanggung jawab atas pekerjaanya indikator 9 menunjukkan skor perolehan rata-rata adalah $77 \%$ dimana memiliki kategori sebagian besar.

\section{Saran}

1) Perlu dilakukan beberapa revisi dalam buku panduan Kerja Praktik Industri sehingga panduan praktikum tersebut dapat dipahami dengan baik oleh mahasiswa praktikan dan dosen pembimbing. Beberapa catatan perbaikan yang diusulkan seperti tata cara penulisan laporan dan hal lainnya.

2) Lama waktu KPI perlu dipertimbangkan agara mahasiswa mampu beradaptasi dan memeproleh wawasan tentang dunia industri secara maksimal.

3) Dosen pembimbing dan pengampu matakuliah dapat memperbaiki menyiapkan materi-materi praktek lapangan dengan baik sehingga dapat meminimalisir misunderstanding mahasiwa tentang pelaksanaan praktek lapangan di sekolah.

\section{DAFTAR PUSTAKA}

Arifin, M. 2014. Analisis dan Perancangan Sistem Informasi Praktek Kerja 
Lapangan Pada Instansi/ Perusahaan. Jurnal Simetris Vol 5.

Gardner, H. 2013. Multiple Intelligences. Terj. Yelvi Andri Zaimur. Jakarta: Daras Books.

Khalil, O.E.M. 2015. Students experience with the business internship program at Kuwait University. The International Journal of Management Education. 202-2017

Mukhadis. A. 2014. Pengembangan Mindset Emulasi Sebagai Orientasi Pembelajaran Bidang Teknologi dan Kejuruan di era globalisasi. Makalah. Tidak Diterbitkan.

Purwaningsih, dkk. 2017. Soft Skills pada Pelaksanaan Magang Dunia Usaha/Dunia Industri. Jurnal "Tata Arta" UNS, Vol. 3, No. 2, hlm 1120.

Robinson. 2000. What Are Employability Skills. Alabama Cooperative Extention System, 1(3), (Online), (http://www.aces.edu/crd/workforc e/publication/employability-skills, diakses 18 Agustus 2008).

Sudjimat, DA. 2011. Kecakapan Kemampu-Kerjaan Siswa SMK Bertaraf Internasional dan Pengembangannya dalam Pembelajaran. Jurnal Ilmu Pendidikan, Jilid 17, Nomor 4, Februari 2011, hlm. 279-286.

Syahroni, F. 2014. Persepsi Siswa Terhadap Manfaat Pelaksanaan Praktek Kerja Industri Di SMKN 1 Lembah Gumanti. Dari jurnal administrasi pendidijan Vol 2 No 1 .

Tridiana dan Rizal. 2020. Keterampilan Guru Abad 21 di Sekolah Menengah Kejuruan (SMK). Jurnal Imiah Pendidikan dan Pembelajaran. pISSN : 1858-4543 e-ISSN : 26156091.
Trilling, Bernie and Fadel, Charles. 2009. 21st Century Skills: Learning for Life in Our Times, John Wiley \& Sons, 978-0-47-055362-6.

Wijaya. Dkk. 2016. Computer-Mediated Communication (CMC) sebagai penyelaras pembelajaran abad 21 pada program keahlian teknik komputer dan informatika di SMK. Prosiding Seminar Nasional Pendidikan Kejuruan, Universitas Negeri Malang. ISBN: $978-979-$ $49589-8-8$. 